\title{
Egészségügyi képességtervezés a COVID-19 pandémia időszakában
}

Dr. Fejes Zsolt orvos ezredes, $\mathrm{PhD}$,

Dr. Kopcsó István orvos dandártábornok, ${ }^{\star} \mathrm{PhD}$, címzetes egyetemi tanár,

Dr. Zsíros Éva orvos őrnagy,

Dr. Péter Ádám orvos őrnagy,

Balázs Péter mérnök őrnagy

Kulcsszavak: katasztrófa, katasztrófaorvostan, COVID-19 pandémia, stratégia, képesség, Katasztrófa Helyreállító Egység

A COVID-19 világjárvány következtében kialakult globális egészségügyi vészhelyzet a Föld összes kontinensét és teljes lakosságát érintette és érinti napjainkban is. A világjárvány komplex kihívásai folyamatosan próbára teszik az érintett országok egészségügyi ellátórendszereit. A járvány elleni védekezés során dinamikusan változó és fokozódó kihívások rámutatnak arra, hogy hasonló események bekövetkezésével a jövőben is nagy valószínüséggel számolnunk kell, azonban ezekre nem vagyunk megfelelö stratégiákkal felkészülve. Szembesülve a jelen helyzet kihívásaival, elemezve azok katasztrófaorvosi ellátásra vonatkozó részleteit, a Magyar Katonai Katasztrófaorvosi Társaság kidolgozta egy, az ellátás javítását szolgáló új képesség összetevőinek stratégiai besorolását, javasolt szerkezeti összetételét, várható feladatainak körét és várható beszerzési költségeit. A kidolgozásra került ellátó egységnek a „Katasztrófa Helyreállító Egység” nevet adta, amelynek angol elnevezése - Disaster Relief Unit.

A COVID-19 világjárvány következtében kialakult globális egészségügyi vészhelyzet a World Health Organization (WHO) által 2020. március 11-én került kihirdetésre, amely vészhelyzet a Föld összes kontinensét és teljes lakosságát érinti [1]. A világjárvány kitörésével 2020-ban a Föld országai olyan komplex kihívással szembesültek, amely alaposan megrengette biztonságérzetüket, megmutatta társadalmi és gazdasági sebezhetőségüket, és napjainkban is folyamatosan próbára teszi az érintett országok egészségügyi ellátórendszereit [2].

* Jelenleg orvos vezérörnagy 
A járvány elleni védekezés során dinamikusan változó, újabb és újabb, megoldásra váró feladatok, kihívások megmutatták, hogy hasonló események bekövetkezésével a jövőben is nagy valószínűséggel számolni kell, szakterületi védekezési stratégiák kidolgozása, felülvizsgálata válik szükségessé annak érdekében, hogy jövőnk biztonságos alakításának aktív tervezői és alakítói lehessünk.

\section{A projekt előzménye}

Az Európai Bizottság, Európai Polgári Védelemi És Humanitárius Műveletek Föigazgatósága [3] „A határokon átívelő súlyos egészségügyi vészhelyzetekre reagáló egészségügyi válaszlépések kidolgozása és egészségügyi védőeszköz készletképzési projektje" keretén belül kezdeményezte a COVID-19, illetve hasonló vészhelyzetek hatékony kezelésére egészségügyi készletek létrehozását (pl. lélegeztetőgépek, labor szakanyagok, oltóanyagok, gyógyszerek, egyéni védőfelszerelések). Az elképzelések szerint a készletek a programra jelentkező tagországokban kerülnek elhelyezésre és raktározásra, míg felhasználásuk azokban a tagországokban történhet meg, ahol egy kialakuló katasztrófa-egészségügyi helyzet indokolttá teszi azt a nemzeti ellátóegységek kapacitás-, és/vagy képességhiánya okán.

A kidolgozásra kerülő képesség készletei, eszközösszetevői egy veszélyhelyzeti reakció harmadik körös elemeként kerülnek felhasználásra, akkor, amikor a nemzeti egészségügyi ellátó saját kapacitásainak felhasználását követően (1. kör) központi-, vagy más egészségügyi ellátótól - beleértve a nemzetközi együttmüködés lehetőségét is - kért és kapott segítséget (2. kör), de ennek felhasználását követően is szüksége van további szakmai támogatásra (3. kör).
Az unió RescEU kezdeményezésének keretén belül a tervezett beszerzéseket az Európai Bizottság 100\%-os intenzitással támogatja, összesen 300 millió EUR-keret erejéig [4]. Magyarország részéről az Országos Katasztrófavédelmi Főigazgatóságot bízták meg azzal, hogy indítsa el Magyarország csatlakozási kérelmét a kezdeményezéshez. Az ajánlás kidolgozásának idején több tagország (Finnország, Németország, Románia) is kifejezte részvételi szándékát az együttműködési programban.

\section{A szakmai ajánlás célja}

Jelen Szakmai ajánlás elkészítését a 2020ban kialakult, a Föld szinte valamennyi országát érintő Covid-19 világjárvány terjedése, és az ezzel kapcsolatban kialakult globális egészségügyi vészhelyzet, valamint az erre adott válaszlehetőségek aktív keresése motiválta.

Összefoglalva a koronavírus világjárvány 2020 -as nagy létszámú betegellátásra vonatkozó tapasztalatait, egybevetve ezt a fentebb említett projektben történő részvétel lehetőségeivel, a Magyar Katonai Katasztrófaorvosi Társaság, mint felelős tudományos szakmai testület, ajánlást fogalmazott meg a jelenleg zajló világjárvánnyal kapcsolatosan, a tömeges egészségügyi ellátás kiürítési fázisára, valamint annak elméleti és gyakorlati megvalósítási lehetőségére vonatkozóan. Tettük ezt annak reményében, hogy az általunk megtervezett strukturális egység hatékony segitséget nyújthat egy esetleg ismételten kialakuló, nagy beteglétszámmal járó katasztrófa következményeinek felszámolásában, kárenyhítésében. A kidolgozásra került ellátó egységnek a „Katasztrófa Helyreállító Egység" nevet adtuk. Angol elnevezése azonban - Disaster Relief Unit - közelebb áll a feladattartalom 
valós leírásához, így a javaslatban is ennek rövidítését használjuk. A DRU a kiürítő képesség szabályozásán keresztül látja el feladatát, három eltérő felszereltségi szinten, három eltérő súlyosságú betegcsoport ellátását végezve. Moduláris szerkezete által folyamatosan biztosítható a szükséges mennyiségü betegágy, a kapcsolt és eltérő szintű ellátást biztosító eszközei révén pedig a progresszív betegellátás folyamata. Szerkezeti rendszere nagy fokú mobilitást, könnyü és gyors telepítést tesz lehetővé.

A kidolgozott anyag célja, hogy segítségével egy olyan, újszerű, a jelen kihívásaira reagáló ellátó egység kerüljön kialakításra, amely képes biztosítani a progresszív betegellátás folytonosságát, ezáltal képes csökkenteni az aktuálisan jelen lévő, de akár évekig is fennálló katasztrófahelyzet hátrányos következményeit. Jelen ajánlás lehetőséget biztosít arra, hogy a későbbiekben szakmai, stratégiai elképzelés részét képezze a koronavírus világjárványhoz hasonló, országhatárokon túlnyúló regionális, vagy akár kontinentális méretü, jellegében azonos, nem sebészeti típusú betegellátási igény megjelenése esetén. A szakmai ajánlás közvetett célja, hogy felhívja a figyelmet a jövőbeni nemzeti stratégiaalkotás közvetett folyamatában a katona-, a katasztrófa-, és a rendvédelmi medicina kiemelt fontosságára.

Hangsúlyozni kívánjuk, hogy az ajánlás elméleti jellegü, amely adott esetben multidiszciplinális tudományos konszenzus tárgya lehet. Egyben feltételezi azt a szükséges mértékü anyagi-, és megfelelő kvalitású humán erőforrás rendelkezésre állást, melyet a korábban már említett Európai Bizottság, Európai Polgári Védelemi és Humanitárius Müveletek Főigazgatósága által kezdeményezett program biztosíthat számára [5].

\section{Elökészítési, elemzési folyamat}

A szakmai ajánlás előkészítő, elemző fázisában összeállítottuk azon meghatározó inputokat, amelyek a katasztrófaesemény outputját alapvetően, az egészségügyi válaszlehetőségeket pedig jelentősen befolyásolják. Ezen faktorok csoportosításának célja az volt, hogy meghatározzuk a katasztrófára adott egészségügyi válaszok, beavatkozások és kapacitások körét, és így azonosítsuk a beavatkozásra alkalmas pontokat.

Ennek az elvárásnak megfelelően vizsgálatra, csoportosításra kerültek a katasztrófa típusok jellegük, időbeni jellemzőik, sérült-/sebesült-/beteg ellátási igényeik jellemzői, valamint közvetlen és közvetett következményeik alapján [6]. Ugyancsak vizsgálatra és összehasonlításra kerültek azok az egészségügyi képesség összetevők, amelyek napjaink katonai és humanitárius müveleteinek fö elemeit alkotják [7].

\section{A kockázati tényezők azonosítása}

A probléma azonosítás és elemzés folyamatában első lépésként - áttekintve a katasztrófák természetét, jellegét - elkészült egy földrajzi régió specifikus, Európára vonatkozó rizikó elemzési mátrix, amelyben a különböző lehetséges katasztrófák alacsony, közepes vagy magas előfordulási rizikó alapján kerültek kategorizálásra.

A katasztrófa események következményeit időbeni megjelenés alapján két csoportba soroltuk (azonnali és elhúzódó), illetve további három csoportot alkotva, hármas kategória csoportba vontuk ezeket tömeges egészségügyi ellátási igényük szerint (sürgősségi, nem sürgősségi, nem tömeges) (1.ábra). 


\begin{tabular}{|c|c|c|c|c|c|c|c|c|}
\hline & Alacsony & Közepes & Magas & $\begin{array}{l}\text { Azonnali } \\
\text { eü. } \\
\text { követ- } \\
\text { kezmény }\end{array}$ & $\begin{array}{c}\text { elhúzódó } \\
\text { eü. } \\
\text { követ- } \\
\text { kezmény }\end{array}$ & $\begin{array}{l}\text { Tömeges } \\
\text { sürgős- } \\
\text { ségi } \\
\text { ellátási } \\
\text { igény }\end{array}$ & $\begin{array}{c}\text { Tömeges } \\
\text { ellátási } \\
\text { igény }\end{array}$ & $\begin{array}{c}\text { Tömeges } \\
\text { ellátást } \\
\text { nem } \\
\text { igényel }\end{array}$ \\
\hline Adott időpontban nem gyógyítható fertőző betegségek megjelenése & & & & & $\mathrm{x}$ & & $x$ & \\
\hline Járványok megjelenése & & & & & $x$ & & $X$ & \\
\hline Adott területen nem jellemző fertőző betegségek megjelenése & & & & & $x$ & & $X$ & \\
\hline \multicolumn{9}{|l|}{ Emberi hiba okozta biológiai katasztrófa } \\
\hline Szándékosan előidézett biológiai katasztrófa & & & & $X$ & & $\mathrm{X}$ & & \\
\hline Földrengés, földcsuszamlás, vulkánkitörés, cunami & & & & $X$ & & $x$ & $X$ & \\
\hline Árvíz & & & & & & & $x$ & $x$ \\
\hline Extrém hömérséklet emelkedés, tartós höhullám & & & & & $x$ & & $X$ & \\
\hline Extrém hőmérséklet csökkenés, tartós hideghullám & & & & & $x$ & & & \\
\hline Nagy kiterjedésű tűzvész, erdő-, bozóttűz & & & & & & & & $x$ \\
\hline Veszélyes és/vagy radioaktív anyagok kiáramlása & & & & $x$ & & & & \\
\hline Veszélyes légszennyezés & & & & & $x$ & & $x$ & \\
\hline Politikai válság & & & & & $x$ & & $x$ & \\
\hline Terrorizmus & & & & $X$ & & & & \\
\hline A nemzetgazdaság összeomlása & & & & & $x$ & & $x$ & \\
\hline Migráció & & & & & $x$ & & $x$ & \\
\hline Polgárháború, helyi háború, koalíciós háború & & & & $x$ & & & & \\
\hline
\end{tabular}

1. ábra. Tömeges egészségügyi ellátási igénnyel járó katasztrófák

(Forrás: a szerzők saját ábrája)

\section{Katasztrófaesemények időtényezőinek egészségügyi vonatkozásai}

A kidolgozás következő lépésében elemeztük a katasztrófaeseményeket időtényezők alapján, és a felmerülő egészségügyi ellátási igény szerint is, ahol három csoportot alkottunk meg (gyors lefolyású, közepes lefolyású, lassú lefolyású események), melyek jellemzőit az alábbiakban foglaltuk össze.

Fontos kiemelni, hogy a katasztrófa lefolyásának fázisai nem keverendők a katasztrófaesemény időtényezőivel. Míg az első az esemény folyamatának időbeni változói mentén mozog, a dinamikus változótól a nyugalmi fázis felé haladó folyamat, addig a gyors-közepes-lassú lefolyás magának a katasztrófaesemény kialakulásának időtényezőit írja le.

\section{Gyors lefolyású katasztrófa események}

Egyik pillanatról a másikra következik be, másodpercek, percek történését jelenti. Felkészülni rá, előre jelezni ritkán lehet.

Jellemző események: földrengés, ipari katasztrófák, terror események.

- Nincs lehetőség felkészülésre, csak a következmény felszámolására, a katasztrófa bekövezése után.

- Hirtelen nagy számú, súlyos állapotú sebesült/sérült egyidejű megjelenése az egészségügyi ellátó rendszerben.

- Diszkrepancia az ellátandók és az ellátok létszáma között;

- Hirtelen jelentkező, aránytalanul nagy egészségügyi erőforrás igény, rövid időn belül;

- Nagy személyi veszteség;

- Szervezetlenség; 
- Tervezés, felkészülés hiányában átgondolatlan szakmai, személyi, gazdasági döntések;

- Gyorsan kimerülő készletek;

- Alacsony effektivitás.

\section{Közepes lefolyású katasztrófa események}

Az esemény bekövetkezése órák, napok múlva várható, esetenként elöre jelezhető. Van lehetőség a felkészülésre és a védekezés bizonyos szintü megszervezésére, megelözési pontok, rendszabályok beiktatására. A lakosság tájékoztatása megoldható. Jellemző események: biológia katasztrófák, járványok, árvíz.

- Van lehetőség a FELKÉSZÜLÉSRE és részleges MEGELŐZÉSÉRE, a katasztrófa bekövetkezése ELÖTT.

- NAGY SZÁMÚ sebesült/sérült/beteg megjelenése az egészségügyi ellátó rendszerben, de jellemzően NEM HIRTELEN, NEM EGYIDŐBEN DE NAGY INTENZITÁSSAL.

- Nagy egészségügyi erőforrás igény hosszabb időn keresztül;

- Diszkrepancia az ellátandók és az ellátok létszáma között;

- Kisebb volumenü személyi veszteség;

- Kezdeti szervezetlenség, amely idővel egyre csökken;

- Esetlegesen kimerülő készletek;

- Tervezés, felkészülés mellett átgondolat szakmai, személyi, gazdasági döntések;

- Effektív müködés és egészségügyi ellátás.

\section{Lassú lefolyású katasztrófa események}

Bekövetkezésére számítani lehet. Részben fel lehet készülni az esemény bekövetkezésére, annak „kezelésére”, más- részt a bekövetkezését követően erők, eszközök megfelelő átcsoportosításával meg lehet akadályozni az elterjedést, fel lehet készülni a következmények felszámolására.

Jellemző események: fegyveres konfliktus, háború, migráció.

- Van lehetőség a FELKÉSZÜLÉSRE és eredményes KÁRCSÖKKENTÉSRE, -MEGELÖZÉSÉRE, a katasztrófa bekövetkezése ELÖTT.

- Jellemzően NAGY SZÁMÚ sebesült/ sérült/beteg megjelenése az ellátórendszerben, DE nem hirtelen, nem egyidőben, hanem FOLYAMATOSAN, bizonyos betegcsoportok esetében ELŐRE LÁTHATÓAN.

- Nagy egészségügyi erőforrás igény hosszabb időn keresztül;

- Diszkrepancia az ellátandók és az ellátok létszáma között;

- A személyi veszteség aránya jellemzően nem az egészségügyi ellátás képességétől függ;

- Kezdeti szervezetlenség, amely idővel egyre csökken;

- Folyamatos, szervezett utánpótlás mellett csak átmenetileg kimerülö készletek;

- Tervezés, felkészülés mellett átgondolt szakmai, személyi, gazdasági döntések;

- Effektív müködés és egészségügyi ellátás.

- Kezdeti szervezetlenség, amely idővel egyre csökken;

- Folyamatos, szervezett utánpótlás mellett csak átmenetileg kimerülö készletek;

- Tervezés, felkészülés mellett átgondolt szakmai, személyi, gazdasági döntések;

- Effektív müködés és egészségügyi ellátás. 


\section{Katasztrófák következményeinek kategorizálása}

Következő lépésben a katasztrófák egy relatíve ritkán elemzett aspektusból, az egészségügyi ellátórendszerre gyakorolt hatás oldaláról kerültek elemzésre. A közvetett és közvetlen következmények jellemzői az alábbiak szerint alakultak:

1. Közvetlen következmények:

- speciális sérüléscsoportok megjelenése,

- speciális ellátási igények megjelenése,

- nagy számú komplikált, súlyos sérült/ beteg egyidejű megjelenése,

- nagy számú szövődményes eset megjelenése,

- magas mortalitás,

- ellátórendszer kapacitás- és képességhiánya fokozott sérült/betegáramlás miatt,

- ellátórendszer kapacitás- és képességhiánya csökkent kiürítő képesség miatt.

2. Közvetett következmények:

- egészségügyi ellátórendszer kiterjedt működési zavara,

- ellátási kapacitás-és képesség elégtelensége vagy tartós hiánya,

- infrastruktúra károsodása,

- közegészségügy, járványügyi helyzet fokozatos romlása,

- halasztható mütéti beavatkozások számának emelkedése,

- ellátási prioritásban hátrébb sorolt esetek számának emelkedése,

- krónikus esetek számának folyamatos emelkedése,

- romló állapotú betegek számának fokozatos emelkedése.

A közvetlen következmények egy részének elhárítására szakszerü, előrelátó, proaktív tervezéssel fel lehet készülni.
Habár a fokozott sérült/betegáramlásra és az ebből adódó átmeneti kapacitáshiányra az ellátórendszer általában nem rendelkezik impakttal, a kiürítő kapacitás forszírozott, terv- és szakszerü, valamint protokoll alapú menedzselése biztosíthat egyfajta egyensúlyt a progresszív betegellátás folyamatában.

A közvetett következményekre történő felkészülés ugyancsak elözetes tervezést igényel, amely rendszerint a katasztrófák lezajlását, a kárenyhítést és kárfelszámolást követően gyakorlatilag azonnal, a tapasztalatok elemzésével és feldolgozásával kezdődik.

\section{COVID-19 világjárvány várható következményei}

A COVID-19 világjárvánnyal kapcsolatban az elmúlt hónapok történései nyilvánvalóvá tették, hogy a folyamat csak átmeneti lassulást, javulást mutat. Most, a második hullám kezdeti fázisában már látható, hogy várhatóan nagyobb érintettséggel számolhatunk mind a megfertöződött egyének, mind a súlyosan megbetegedők, mind a betegség következtében elhunytak számának vonatkozásában, valamint a betegek nagyobb százaléka szorulhat majd lélegeztetésre, súlyosabb esetben intenzív ellátásra. Mindez sajnos azt is jelentheti, hogy az ellátórendszerek gyorsan elérik majd kapacitásuk maximumát, mind ágyszámok, mind eszközök, mind képzett humán erőforrás vonatkozásában [8] (2. ábra).

\section{A COVID-19 pandémia tömeges egészségügyi ellátással kapcsolatos jellemzői}

A progresszív betegellátás során kritikus diagnosztikai, terápiás, elhelyezési, ápolási és kiürítési rendszerelemek 


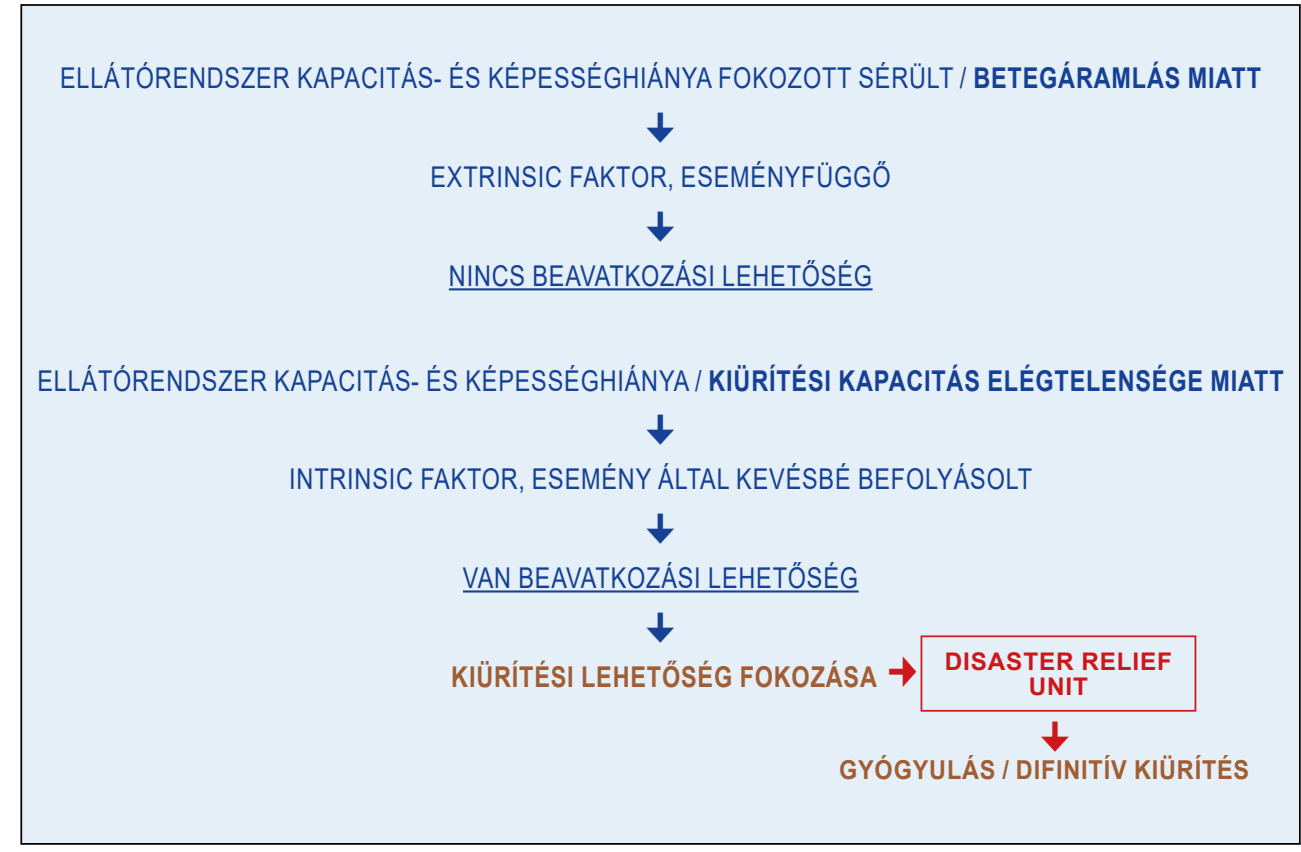

2. ábra. COVID-19 világjárvány várható következményei

(Forrás: a szerzők saját ábrája)

- helyszíntől, rendelkezésre álló anyagi és humán erőforrástól függetlenül nemzetközi példákon keresztül kerültek elemzésre. [9]

A koronavírus világjárványra adott hatékony válaszok legtöbbje újfajta megközelítést igényelt, és legtöbbször szokatlan megoldások formájában mutatkozott meg, sok esetben módosítva a konvencionális járványügyi stratégiákon, szabályokon. Ennek legfőbb okait az elemzések során abban láttuk, hogy:

- egy, a gyakorlatban eddig ismeretlen betegséggel állunk szemben, melynek sem kórokozója, sem annak természete, sem a betegség etiológiája, sem kiváltott tünetei, sem a betegség lefolyásának dinamikája, sem specifikus kezelése nem ismert korábbról,

- az egészségügyi ellátórendszerrel szemben tartósan megmutatkozó követel- mény a kezdetben fokozatosan, majd exponenciálisan emelkedő számú, összességében rendkívül nagy volumenü beteg ellátása,

- fertőző, relatíve magas reprodukciós rátájú, gyorsan terjedő megbetegedés, melynek inkubációs ideje is relatíve hosszú ideig tart,

- a betegség kimenetele bizonytalan, sokszor váratlan még az egyébként egészséges, alapbetegséggel nem rendelkező populáció tagjainak körében is,

- nem rendelkezünk információval korábbról az ismert tünetmentes, enyhe tünetes, súlyos tünetes és halálos esetek egymáshoz viszonyított arányáról,

- a nagy létszámú koronavírusos esetek ellátása tartósan, az egészségügyi ellátórendszer mindennapi feladatai mellett jelentenek további extra terhelést az ellátó rendszer és az ellátó személyzet részére, 
- a betegség, mint fertőző megbetegedés, jelentősen korlátozza a normál betegellátás folyamatát,

- kiemelt problémává válik az egészségügyi dolgozók érintettsége, részben fokozott megfertőződési kockázatuk, megfertőződési rátájuk, és megfertőződésük esetén munkából történő bizonytalan ideig tartó távolmaradásuk miatt.

\section{Az egészségügyi képességtervezés folyamata}

A jelen helyzetben - többnyire a pandémia első hullámából származó - rendelkezésünkre álló szakmai tapasztalatok alapján kerültek meghatározásra azok a relevanciával bíró, lehetséges beavatkozási pontok, amelyek véleményünk szerint láthatóan nehezítették, és továbbra is nehezítik a betegellátás folyamatát.

Vizsgálatra kerültek azok a katasztrófa lefolyási periódusban mutatkozó pontok, ahol a szerkezeti változtatástól pozitív változás várható az ellátás folyamatában. Valamennyi elemzés eredménye, de legfóképpen a betegek ellátását szakszerüen végezni képes akut kórházi ágyak tartós foglaltsága, a kiürítő képesség hiánya vagy annak ineffektív volta miatt azt mutatta, hogy olyan strukturális rendszerbeli módosítás szükséges - a rendszer fenntartható müködése érdekében - amely mind létszámában, mind ellátási profiljában eltér az eddig megszokottaktól.

Az elemzések eredményeként ezek közül kiemelkedett az akut ágykapacitásra közvetlen hatással bíró kiürítési sebesség és kiürítő képesség, amely homokóraszerűen szűkítette a progresszív ellátási folyamatot.

A szakmai ajánlás kidolgozásának kiindulópontját az a gondolat jelentette, hogy az egyre inkább krónikussá váló járvány- helyzetben, a kezdeti operatív beavatkozásokon alapuló helyzetkezelési döntéseket, cselekvési elképzeléseket, szükségszerüen fel kell váltsák olyan stratégia elképzelések, amelyek az ellátási folyamatba közvetlenül beavatkozva, a struktúra megváltoztatásával teszik hatékonyabbá az ellátást.

$\mathrm{Az}$ események kronológiáját 2020. februárjától végig követve látható, hogy a megtervezett operatív lépésekre sok esetben váratlan reakciót kaptuk, és a betegség nem úgy reagált ezekre az elképzelésekre, mint ahogyan azt vártuk. Éppen ezek miatt a tapasztalatok és korábban nem ismert összefüggések miatt vált szükségessé a rendelkezésre álló reagáló képességek szerkezet szerinti felülvizsgálata a képességösszetevők, kapacitás adatok, hatékonyság, komplexitás és a mobilitás kritériumainak oldaláról.

A strukturális felülvizsgálat szempontrendszere további három pontban került meghatározásra:

- a folyamatosan, nagy létszámban érkező betegek szakszerű ellátását akadályozó strukturális tényezők beazonosítása;

- a betegellátási folyamat hatékonysági és minőségi mutatóinak növelésével járó beavatkozási pontok beazonosítása;

- szerkezetmódosítási lehetőségek beazonosítása azokon a pontokon, ahol a struktúra megváltoztatásának segítségével jelentős javulás érhető el a súlyos és középsúlyos betegek állapotának biztonságos fenntartásában, illetve állapotának javulásában.

Fentiek alapján kialakult a megtervezett képességre vonatkozó általános követelmények rendszere, amely az alábbiak szerint alakul:

- rendelkezzen tömeges egészségügyi ellátási képességgel; 
- legyen alkalmas azonos betegségcsoportba tartozó, de eltérő fizikális állapotú, változó terápiás és ápolási igényü beteg ellátására;

- rendelkezzen a nagy fokú mobilitás képességével;

- tegye lehetővé a képességösszetevők egyenkénti, moduláris szerkezetben történő felhasználhatóságát;

- legyen képes a betegek stabilizált állapotának fenntartására, megkezdett terápiás beavatkozások folytatására;

- legyen képes korlátozott (intenzív ellátás, mütéti és intervenciós beavatkozások kivételével), egészségügyi ellátás nyújtására az intenzív terápiás ellátási időszaktól a gyógyulásig vagy a definitív kiürítésig;

- legyen képes további kiegészítő funkciókat biztosító modulokhoz kapcsolódni (képalkotó diagnosztika, labor diagnosztika);

- rendelkezzen a modulszerü ágyszám bővítés képességével;

- legyen képes a beteg/sérült állomány ellátásához kapcsolódó adminisztrációs tevékenység végzésére, és annak informatikai rendszeren keresztül történő fogadására/továbbítására.

A képességcsomag megtervezésekor fontos a katonai terminológiához hasonló könnyü, közepes és nehéz formátumok kialakítása, és az ezekhez szervesen kapcsolódó ágyszámadatok modulonkénti megtervezése. A rendszer komplexitása magából a szerkezetből (könnyü-közepes-nehéz), annak modularitásból és a nagy fokú mobilitásából együttesen adódó képességjellemző.

Az MKKOT orvosszakmai csoportja a DRU megtervezésével olyan képességcsomag létrehozására törekedett, amely alkalmas a COVID-19 pandémia, és az ahhoz hasonló betegségek, kiterjedt járványok esetén a folyamatos egészségügyi ellátásra biztosítására és kárenyhítésére.

\section{A DRU helye és szerepe a progresszív betegellátási folyamatban}

\section{A DISASTER RELIEF UNIT müködésé-} nek lényegi eleme az orvosi felügyeletre szoruló, de a meglévő kapacitással már nem kezelhető betegek számára megfelelő szintű ellátás biztosítása, legyen az egyszerű obszerváció vagy akár a legmagasabb szintü intenzív ellátás.

A betegek/sérültek orvosi kezelése ezen egységekben folyik, az igénylő által meghatározott kapacitással és összetételben (3. ábra).

\section{A DRU jellemzői}

Moduláris, variálható, a progresszivitási szinteket modellezö, nagyszámú sérült/ beteg befogadására alkalmas nagy mobilitású rendszer.

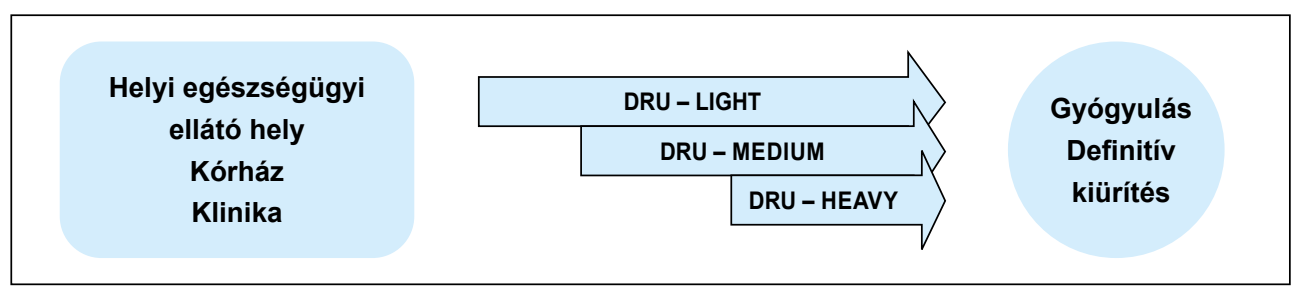

3. ábra. A DRU helye és szerepe a progresszív betegellátási folyamatban

(Forrás: a szerzők saját ábrája) 
A DRU alapegysége 6 darab sátorból áll, amely egyben a lehívható legkisebb egység.

A DRU felszereltség alapján három kategóriába sorolható:

- Könnyü / Light

- Közepes / Medium

- Nehéz / Heavy

\section{DRU - LIGHT modul}

Alkalmazásának célja kizárólag a fektető kapacitás növelése, orvosi beavatkozás nem, vagy csak minimális formában történik, egységén belül invazív beavatkozásra nincs lehetőség. Jellemzően emelt szintü ápolási feladatok, általános ápolási feladatok és obszerváció végrehajtására alkalmas egység.

Tervezett mennyiség:

50 egység $=300$ sátor $=2400$ ágy

50 gység $=100$ aggregátor $=300$ HVAC

(4. ábra)

1 egység főbb felszerelései:

- $6 \mathrm{db}$ sátor héjazat egyben (szükség esetén így túlnyomás kialakítása lehetséges)
- $6 \mathrm{db}$ HVAC

- $2 \mathrm{db}$ aggregátor + elektromos energiaellátó hálózat és világítás sátranként

- 48 pneumatikus ágy/tábori ágy

- $24 \mathrm{db}$ infúziós állvány

- 6 db müanyag eszköztároló

Műszaki paraméterek:

- pneumatikus vázszerekezet

- $40 \mathrm{~m}^{2} /$ sátor $=240 \mathrm{~m}^{2} / \mathrm{DRU}-\mathrm{L}$ egység

- összecsomagolt sátor: $2 \mathrm{~m}^{2}, 200 \mathrm{~kg}$

Forrásszükséglet (megközelítőleg):

- sátor + HVAC/db: $15000000 \mathrm{Ft}+$ ÁFA

- aggregátor UFO-n/db: $14000000 \mathrm{Ft}$ + ÁFA

- ágy/db: $250000 \mathrm{Ft}+A ́ F A$

Kalkulált bekerülési költség / $50 \mathrm{db}$

DRU-L: 18 000-20 000 Euro

\section{DRU - MEDIUM modul}

A DRU-L kiegészül magasabb szintű ellátásra alkalmas eszközökkel, minden sátor felszereltségéhez tartozik a betegellenőrző monitor, oxigén koncentrátor, a reanimációhoz szükséges sürgősségi kocsi defibrillátorral. A mo-

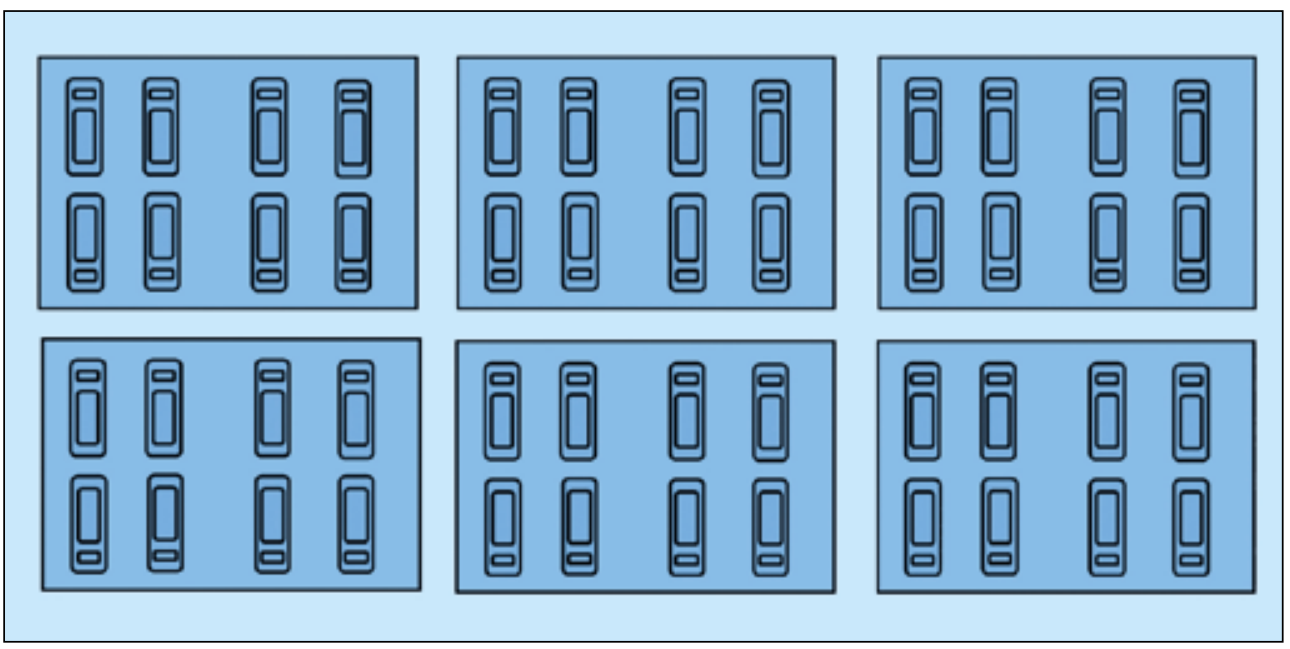

4. ábra. A DRU - LIGHT modul (Forrás: a szerzók saját ábrája) 


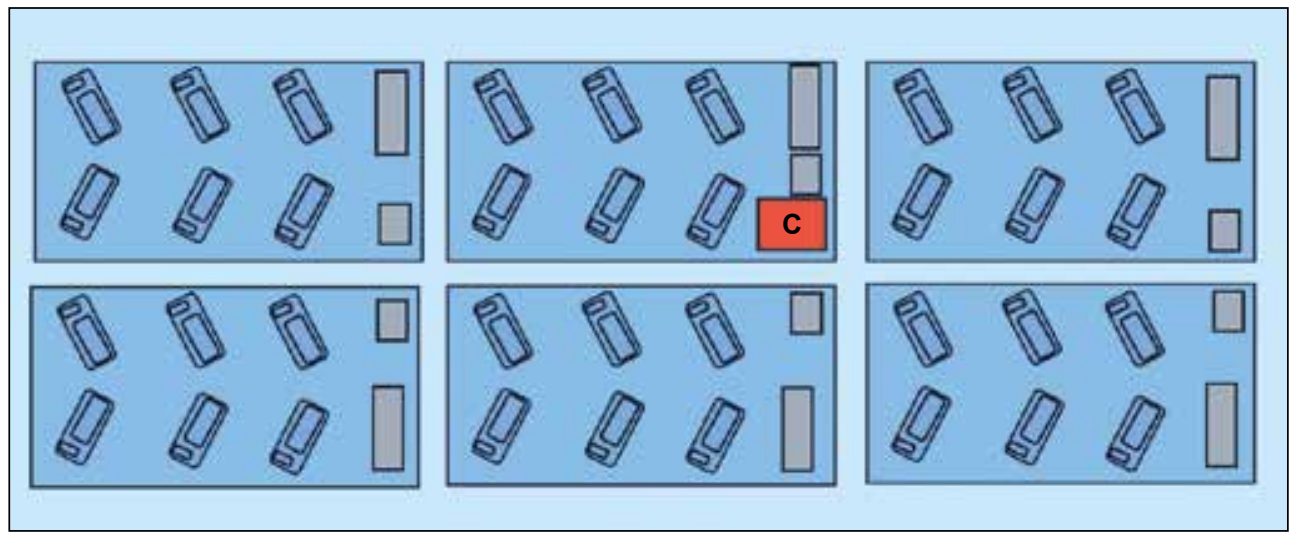

5. ábra. A DRU - MEDIUM modul (Forrás: a szerzök saját ábrája)

dul felszerelése gyógyszerekkel kiegészített.

Tervezett mennyiség:

30 egység $=180$ sátor $=1080$ ágy

30 egység $=60$ aggregátor $=180$ HVAC

(5. ábra)

1 egység föbb felszerelései:

- $6 \mathrm{db}$ sátor héjazat egyben (szükség esetén így túlnyomás kialakítása lehetséges)

- $6 \mathrm{db}$ HVAC

- $2 \mathrm{db}$ aggregátor + elektromos energiaellátó hálózat és világítás sátranként

- 36 kórházi ágy

- $36 \mathrm{db}$ infúziós állvány

- $6 \mathrm{db}$ oxigén koncentrátor

- $6 \mathrm{db}$ mủanyag eszköztároló

- $6 \mathrm{db}$ mủanyag gyógyszertároló

- $18 \mathrm{db}$ betegellenőrző monitor

- $1 \mathrm{db}$ sürgősségi kocsi

Müszaki paraméterek:

- pneumatikus vázszerekezet

- $40 \mathrm{~m}^{2} /$ sátor $=240 \mathrm{~m}^{2} / \mathrm{DRU}-\mathrm{M}$ egység

- összecsomagolt sátor: $2 \mathrm{~m}^{2}, 200 \mathrm{~kg}$

Forrásszükséglet (megközelítőleg):

- sátor + HVAC/db: $15000000 \mathrm{Ft}+$ ÁFA
- aggregátor UFO-n/db: $14000000 \mathrm{Ft}$ + ÁFA

- ágy/db: $788000 \mathrm{Ft}+$ ÁFA

- eszközök/egység: 200000 Euro

Kalkulált bekerülési költség / $30 \mathrm{db}$

DRU-M: 18 000-20 000 Euro

\section{DRU - HEAVY modul}

Intenzív osztály felszereltségü modul. Minden ágy mellett lélegeztetőgép található, egységenként $1 \mathrm{db}$ ECMO készülékkel, és egységenként egy, konténerben települt nagy teljesítményü oxigén koncentrátorral.

Tervezett mennyiség:

15 egység $=90$ sátor $=360$ ágy

15 gység $=30$ aggregátor $=90$ HVAC

(6. ábra)

1 egység főbb felszerelései:

- $6 \mathrm{db}$ sátor héjazat egyben (szükség esetén így túlnyomás kialakítása lehetséges)

- $6 \mathrm{db}$ HVAC

- $2 \mathrm{db}$ aggregátor + elektromos energiaellátó hálózat és világítás sátranként

- 24 kórházi ágy 


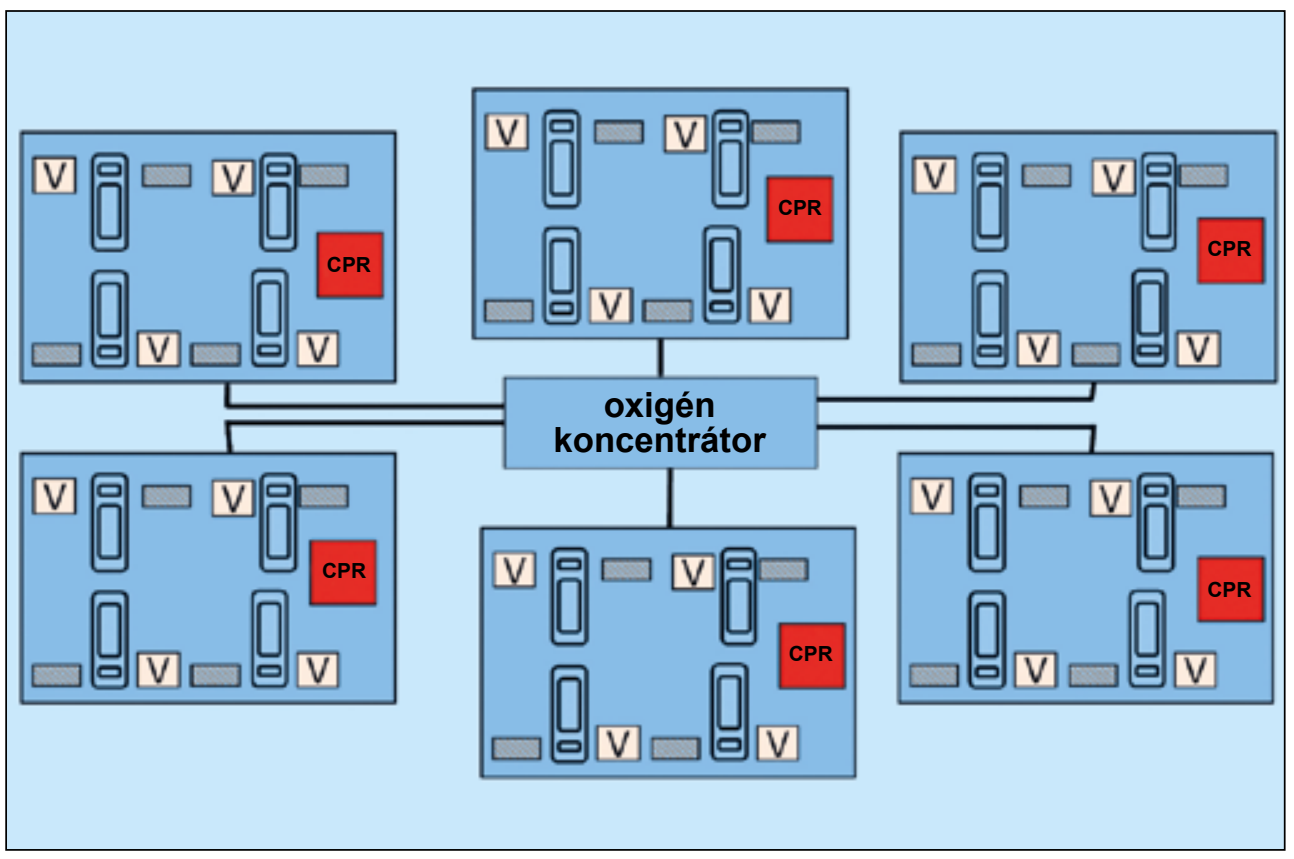

6. ábra. A DRU - HEAVY modul (Forrás: a szerzők saját ábrája)

- $24 \mathrm{db}$ lélegeztetőgép

- $1 \mathrm{db}$ ECMO

- $24 \mathrm{db}$ műanyag eszköztároló

- $12 \mathrm{db}$ váladékszívó

- $48 \mathrm{db}$ perfúzor

- $6 \mathrm{db}$ mủanyag gyógyszertároló

- $24 \mathrm{db}$ betegellenőrző monitor

- 6 db sürgösségi kocsi

- $1 \mathrm{db}$ nagy teljesítményủ oxigén koncentrátor

Müszaki paraméterek:

- pneumatikus vázszerekezet

- $40 \mathrm{~m}^{2} /$ sátor $=240 \mathrm{~m}^{2} / \mathrm{DRU}-\mathrm{H}$ egység

- összecsomagolt sátor: $2 \mathrm{~m}^{2}, 200 \mathrm{~kg}$

Forrásszükséglet (megközelítőleg):

- sátor + HVAC/db: $15000000 \mathrm{Ft}+$ ÁFA

- aggregátor UFO-n/db: $14000000 \mathrm{Ft}$ + ÁFA

- ágy/db: $1000000 \mathrm{Ft}+$ ÁFA

- oxigén koncentrátor: 30000 Euro

- eszközök/egység: 738862 Euro
Kalkulált bekerülési költség / $15 \mathrm{db}$

DRU-M: 17 000-19 000 Euro

A komplett DRU L-M-H jellemzői:

- 95 lehívható egység

- $3840 \mathrm{db}$ ágy

- $570 \mathrm{db}$ sátor

- $570 \mathrm{db}$ HVAC

- $190 \mathrm{db}$ aggregátor

- $180 \mathrm{db}$ kis teljesítményü oxigén koncentrátor

- $900 \mathrm{db}$ betegellenőrző monitor

- $120 \mathrm{db}$ defibrillátor

- $360 \mathrm{db}$ lélegeztetőgép

- $15 \mathrm{db}$ ECMO

- $720 \mathrm{db}$ perfúzor

- 15 db nagy teljesítményü oxigén koncentrátor

Az 50 egység DRU-L, a 30 egység DRU-M és a 15 egység DRU-H megközelítő forrásszükséglete: 56-59000 Euro. 


\section{Speciális kiegészítő egységek}

- RTG-konténer vagy mobil RTG-készülék

- általános laboratóriumi eszközök (vérgáz, kémia, vérkép)

- mikrobiológiai laboratórium (1 sátor, 6-8 láda)

- izolációs transzport kabin

- izolációs kabin

- személyi mentesítő rendszer

- víztisztító képesség

- tömeges kiürítő képesség (betegszállító buszok)

Katasztrófahelyzetekben jól ismert evidencia a képességek közötti kapacitás diszkrepancia fogalma, amely jelen ajánlásban is alapvetés [10]. Mint látható, az orvosszakmai ajánlás azokra a módosítási lehetőségekre koncentrál, amelyek nem egy-egy eszköz nagyobb arányú beszerzésével (pl. lélegeztetőgép, pulzoximeter, páciensmonitorok) növelik az ellátási hatékonyságot, hanem rendszer szinten korrigálják a kialakult diszkrepanciát.

Az MKKOT ennek a kapacitás diszkrepanciának egy bizonyos szeletére kíván a DRU képességcsomag megtervezésével, közzétételével megoldást kínálni, abban a tudatban, hogy megvalósítása nagyobb biztonságot jelenthet majd a katasztrófák egészségügyi ellátási folyamatában. A cikk megjelenésének idején a Magyar Katonai Katasztrófaorvosi Társaság felkért szakorvos tagjai, valamint a külső szakértők bevonásával kidolgozott ajánlás a Magyar Honvédség képviselői által már több nemzetközi fórumon is ismertetésre került (CEDC COVID-19 munkacsoport, Directorate-General European Civil Protection and Humanitarian AID Operation munkacsoport, vagy az Olaszország vezetésével létrehozásra került EMT3 munkacsoport).

\section{Irodalom}

[1] [1] https://lexiq.hu/pandemia

[2] Fejes Zs., S Mihók S.: The role of medical intelligence in the process of defense strategy development during the Covid-19 pandemic. National Security Review, 2020/2: 37-51.

[3] https://ec.europa.eu/echo/what/civil-protection/resceu_en

[4][5]https://ec.europa.eu/echo/news/covid-19commission-creates-first-ever-resceu-stockpile-medical-equipment_en

[6] Below, R., Wirtz, A., Guha-Sapir, D.: Disaster Category Classification and peril Terminology for Operational Purposes, Catholic University of Louvain Centre for Research on the Epidemiology of Disasters - CRED, 2009., 4-8.

[7] AJP-4.10 Allied Joint Doctrine For Medical Support, Edition C, 2019

[8] https://eur-lex.europa.eu/legal-content/HU/ TXT/HTML/?uri=CELEX:52020PC0405\&from $=\mathrm{EN}$

[9] A 2020. évben azonosított új koronavírus (SARS-CoV-2) okozta fertőzések (COVID-19) megelőzésének és terápiájának kézikönyve. Emberi Erőforrások Minisztériuma szakmai kiadványa, 2020.

[10] Davis, J., Wilson, S., Brock-Martin, A. et al.: The Impact of Disasters on Populations with Health and Health Care Disparities. Disaster Medicine and Public Health Preparedness, 2010, 4(1):30-8.

Col. Zs. Fejes MDMC, PhD,

Brig. Gen. I. Kopcsó MDMC, assistant prof., PhD

Maj. É. Zsíros MDMC,

Maj. Á. Péter MDMC,

Maj. eng. P. Balázs

\section{Medical capability planning during COVID-19 pandemic}

The Global Health Emergency - caused by COVID-19 pandemic - affected all continents and the entire population 
of the Earth. The results of pandemic pose a complex challenge for health care systems foralmost all countries in the World.

The dynamically changing challenges in the fight against the epidemic have shown that similar events are likely to occur in the future, but we are not adequately prepared for them strategically. Faced with the challenges of the current situation, analyzing them with the relevant details of disaster medical care, the Hungarian Military Disaster
Medical Society has developed a strategic classification, structural composition, scope of tasks and valuable procurement costs of new capabilities. The developed unit was named Disaster Recovery Unit.

Key-words: disaster, disaster medicine, COVID-19 pandemic, strategy, capability, Disaster Relief Unit

Dr. Fejes Zsolt o. ezds., PhD 1134 Budapest, Róbert Károly krt. 44. 